\title{
LIVED EXPERIENCES OF WOMAN IN RELATION TO INFERTILITY - A REVIEW OF THE QUALITATIVE RESEARCH
}

UDC 159.942:612.663

\section{Ivana Janković, Jelisaveta Todorović}

\author{
University of Niš, Faculty of Philosophy, Department of Psychology, Niš, Serbia
}

\begin{abstract}
In this article, we have analyzed the experiences of women with infertility. We were interested in what we can learn about their feelings, thoughts and problems by analyzing the results obtained in qualitative research. We analyzed 10 qualitative studies dealing with infertile women. Using the thematic analysis, we identified seven core themes: Motherhood, Stories of Infertility, All Colors of Feelings, Changes in Identity, Complexity of Partnership, Social Environment (Social Support), Coping Strategies. Each selected core theme includes a number of subthemes. The article explains in detail each selected theme, and their justification is supported by appropriate quotations.
\end{abstract}

Key words: experience, infertility, qualitative research, women.

\section{INTRODUCTION}

Infertility is most often defined from the domain of medical discourse. The definition defined by World Health Organization is that infertility is the inability of a sexually active, non-contracepting couple to achieve pregnancy in one year (WHO 2020). Medical reasons that are often associated with female infertility include problems with ovulation, obstruction of the fallopian tubes, or abnormal physical characteristics of the uterus (CDC 2020). Hence, the treatment of infertility problems is primarily associated with medical intervention, the use of drugs, or assisted reproductive technologies (ART) such as in vitro fertilization (IVF). From the domain biopsychosocial theory, infertility is determined as both an acute life crisis and a nonevent with long-term complications for the individual, his or her partner, their relationship, and family and friends. The stressors of infertility occur in existential, physical, emotional, and interpersonal realms and may be beyond the average person's usual coping abilities (Gerrity 2001). Regardless of how infertility is defined and whatever the underlying assumptions of the definition are, there

Received September 29, 2020 / Accepted November 30, 2020

Corresponding author: Ivana Janković

University of Niš, Faculty of Philosophy, Ćirila i Metodija 2, 18000 Niš, Serbia

E-mail: ivana.jankovic@ filfak.ni.ac.rs 
is a consensus in the literature that infertility is stigmatizing (Blyth \& Moore 2001) and that it is one of the most distressing life crises for most people who experience it (Fekkes et al. 2003). For an infertile woman, infertility is inextricably bound with feelings of loss, dysfunction, and shame, and infertile women note the social insensitivity of people who pry, question, and assume biological reproduction is a natural, normative, and even necessary adulthood transition (Abbey, Andrews, \& Halman 1991; Mindes, Ingram, Kliewer, \& James 2003).

Traditionally, in the social sciences, infertility is studied by a quantitative approach. This approach relies on standard instruments and designs and the first studies were conducted at IVF clinics among clinical patients in order to acquire data on the impact of infertility on individuals' mental health and on couples' relationships (Hammerberg, Astbury, \& Baker 2001; Slade, Emery, \& Lieberman 1997). Although such quantification significantly contributes to the understanding of the problem of infertility, it does not access the subjective experience of a woman's infertility. Qualitative work does offer us a way in to understanding the "lived experience" of infertility. Qualitative research can offer "broader and deeper understandings of how men as well as women experience and live with infertility over both the short- and long-term" (Culley, Hudson, \& Hohan 2013, 225). The article takes qualitative research as the focus, shifting away from the quantitative focused work. In the subsequent sections of this article, we will explore the current (limited) knowledge about what we do know about women's experiences of infertility based on qualitative research.

\section{METHOD}

To achieve the goals presented in this article, the researchers had to make a decision on the selection of qualitative studies to analyze, given that it is impossible (and unnecessary) to analyze all qualitative studies on the experiences of women with infertility. The authors chose to analyze the studies from the Saga database, since it includes many relevant journals in the field of social sciences. In order to find the appropriate studies, the following keywords were used to search the database: woman, infertility, experience, qualitative research. With such a search, we came to 10 qualitative studies whose contents can contribute to answering the question of this review article ${ }^{1}$. An overview of the studies is given in Table 1.

All of the studies are in English and have been published in the last 20 years. Studies have been conducted in the USA, Canada, Turkey, Australia, New Zealand, New England, South Africa and Cameroon. In eight studies, the method of data collection was an interview with women who struggled with infertility. The number of interviews ranged from 5 to 50. In two studies, material was collected by searching an online forum on infertility, where posts were left by women, or women and men. The number of analyzed posts was 26 in one study and 438 in another.

${ }^{1}$ The authors are aware that the Sage database contains more studies with the same topic, but they limited themselves to the analysis of 10 studies. 
Table 1 Study characteristics

\begin{tabular}{|c|c|c|}
\hline Reference & $\begin{array}{l}\text { Sample size, } \\
\text { data collection }\end{array}$ & $\begin{array}{l}\text { Method of analysis, } \\
\text { and country of research }\end{array}$ \\
\hline $\begin{array}{l}\text { McBain, D. T \& P. Reeves. "Women's Experience } \\
\text { of Infertility and Disenfranchised Grief". The } \\
\text { Family Journal: Counseling and Therapy for } \\
\text { Couples and Families 27, } 2 \text { (2019): 156-66. }\end{array}$ & $\begin{array}{c}\mathrm{n}=8 \\
\text { interview }\end{array}$ & $\begin{array}{l}\text { Interpretative } \\
\text { phenomenology } \\
\text { analysis, USA }\end{array}$ \\
\hline $\begin{array}{l}\text { Mete, S., S. Fata, \& M. AluşTokat. "Feelings, } \\
\text { Opinions and Experiences of Turkish Women } \\
\text { with Infertility: A Qualitative Study". Health } \\
\text { Informatics Journal 26, } 1 \text { (2020): 528-538 }\end{array}$ & $\begin{array}{l}\text { The writings of } \\
26 \text { women on } \\
\text { Internet forums }\end{array}$ & $\begin{array}{c}\text { Content analysis, } \\
\text { Turkey }\end{array}$ \\
\hline $\begin{array}{l}\text { Ceballo, R., T. E. Graham, \& J. Hart. "Silent and } \\
\text { Infertile: An Intersectional Analysis of the } \\
\text { Experiences of Socioeconomically Diverse African } \\
\text { American Women with Infertility". Psychology of } \\
\text { Women Quarterly 39, } 4 \text { (2015): 497-511. }\end{array}$ & $\begin{array}{c}\mathrm{n}=50 \text {, } \\
\text { interview }\end{array}$ & $\begin{array}{l}\text { Grounded theory, } \\
\text { USA }\end{array}$ \\
\hline $\begin{array}{l}\text { Parry, C. D. "Understanding Women's Lived } \\
\text { Experiences with Infertility: Five Short Stories". } \\
\text { Qualitative Inquiry 10, } 6 \text { (2004): 909-922. } \\
\text { Bell, K. “Constructions of 'Infertility' and Some } \\
\text { Lived Experiences of Involuntary Childlessness". } \\
\text { Affilia: Journal of Women and Social Work 28, } 3 \\
\text { (2013): 284-295. }\end{array}$ & $\begin{array}{l}\mathrm{n}=28 \\
\text { in-depth } \\
\text { interview }\end{array}$ & $\begin{array}{l}\text { A collaborative } \\
\text { approach, North } \\
\text { America, Canada } \\
\text { Phenomenological, } \\
\text { feminist, grounded } \\
\text { theory approach, } \\
\text { Australia }\end{array}$ \\
\hline $\begin{array}{l}\text { Ferland, P., \& L. S. Caron. "Exploring the Long- } \\
\text { term Impact of Female Infertility: A Qualitative } \\
\text { Analysis of Interviews with Postmenopausal } \\
\text { Women who Remained Childless". The Family } \\
\text { Journal: Counseling and Therapy for Couples } \\
\text { and Families 21, } 2 \text { (2013): } 180-188 .\end{array}$ & $\begin{array}{l}\mathrm{n}=12 \\
\text { interview }\end{array}$ & $\begin{array}{l}\text { Exploratory study } \\
\text { including coding and } \\
\text { categorizing processes, } \\
\text { New England }\end{array}$ \\
\hline $\begin{array}{l}\text { Ulrich, M., \& A. Weatherall. "Motherhood and } \\
\text { Infertility: Viewing Motherhood through the Lens } \\
\text { of Infertility". Feminism \& Psychology 10, } 3 \\
\text { (2000): 323-336. }\end{array}$ & $\begin{array}{c}\mathrm{n}=19, \\
\text { interview }\end{array}$ & $\begin{array}{l}\text { Feminist discourse } \\
\text { analysis, } \\
\text { New Zealand }\end{array}$ \\
\hline $\begin{array}{l}\text { Weinger, S. "'Infertile' Cameroonian Women } \\
\text { Social Marginalization and Coping Strategies". } \\
\text { Qualitative Social Work 8, 1(2009): 45-64. }\end{array}$ & $\begin{array}{c}\mathrm{n}=5 \\
\text { interview }\end{array}$ & $\begin{array}{l}\text { Inductive analysis of the } \\
\text { data (search for themes), } \\
\text { Cameroon }\end{array}$ \\
\hline $\begin{array}{l}\text { Steuber, R. K. \& H. D. Solomon. "Relational } \\
\text { Uncertainty, Partner Interference, and Infertility: } \\
\text { A Qualitative Study of Discourse within Online } \\
\text { Forums". Journal of Social and Personal } \\
\text { Relationships 25, 5(2008): 831-855. }\end{array}$ & $\begin{array}{l}\text { Online discu-ssion } \\
\text { board strings and } \\
\text { blogs }(\mathrm{N}=438) \text {, } \\
\text { each entry on a } \\
\text { string or blog was } \\
\text { considered one } \\
\text { unit of analysis }\end{array}$ & $\begin{array}{c}\text { Thematic analysis, } \\
\text { USA }\end{array}$ \\
\hline $\begin{array}{l}\text { Fernandes, P., M. Papaikonomou, \& J. M. } \\
\text { Nieuwoudt. "Women suffering through their } \\
\text { Bodies". South African Journal of Psychology } 36,4 \\
\text { (2006): 851-879. }\end{array}$ & $\begin{array}{c}\mathrm{n}=6 \\
\text { interview }\end{array}$ & $\begin{array}{l}\text { Process of inductive } \\
\text { analysis was used to } \\
\text { 'make sense' of the data } \\
\text { in order to uncover and } \\
\text { make explicit } \\
\text { 'embedded information', } \\
\text { South Africa }\end{array}$ \\
\hline
\end{tabular}


Interpretative phenomenology analysis, feminist discourse analysis, thematic analysis, content analysis, collaborative approach and grounded theory were used as method of analysis. Three of the studies provided limited methodological details but it is clear that the authors conducted inductive analysis of the data in order to identify themes and categories.

The method of analysis of selected studies was thematic analysis (Braun,\& Clarke 2006; Wilig 2013). The included studies were closely reviewed with the goal of identifying core themes and subthemes. The thematic approach was focused on drawing out what the articles reported about a woman's experiences of infertility. The first author carried out inductive coding of data using the MAXQDA program. By analyzing the selected codes, connecting them, core themes and subthemes are formed. The initial set of themes were then checked by the second author - following a discussion, the authors agreed on the final themes to be presented.

\section{RESULTS}

The core themes and subthemes will be presented in the results overview. The core themes that were generated during the review of the literature include: Motherhood, Stories of infertility, All the colors of feeling, Identity changes, The complexity of the partnership, The social environment (social support), and Coping strategies. Each of these seven core themes also contains a number of subthemes.

\subsection{Motherhood}

The story of motherhood is an inseparable part of the story of infertility. In the analyzed studies, the participants spoke about motherhood from different angles and several themes related to motherhood could be identified: Explanations of the desire for children, To be a woman is to be a mother, and The obsession with motherhood.

Explanations of the desire for children - Participants understand the desire for a child and the desire to be realized in the role of a mother in different ways. Some of them see motherhood as a 'natural instinct'. They believe that the desire for a child is biologically determined and that it is the very essence of every woman. There is also an understanding that motherhood is a stage in the development of a relationship. In fact, the birth of a child is perceived as an expression of love between two people who are in a partnership and represents the final phase in its development - the symbolic coronation of the partnership. Also, the desire for a child is associated with a social expectation. It has often been argued that the socialization of girls contributed to women's expectation of motherhood (Ulrich \& Weatherall 2000). In addition to the above-mentioned, there is an understanding that motherhood and the desire for a child is the result of a conscious choice that a woman makes at a certain stage of her life. When making a decision to have a child, women also assess their age, financial position and relationship stability and based on that decide when the right time for having a child would be (Bell 2013; Ulrich \& Weatherall 2000).

To be a woman is to be a mother - The message that womanhood equals motherhood is pervasive in modern societies and is internalized by many women. The understanding that motherhood is an indispensable part of a woman's identity is highly present in women's narratives. Many women identified that becoming a mother isvery important to them, fora social, psychological and physical sense of adequacy and completeness (Ferland \& Caron 
2013; Ulrich \& Weatherall 2000). With such an understanding, women who struggle with infertility identified themselves as incomplete women, they subsequently viewed themselves as flawed and deficient in fundamental ways. Emotionally, I felt that I was not complete, because I had not had a child. I didn't feel like I was a complete woman (Ceballo, Graham \& Hart 2015, 502). The data show that the motherhood mandate appeared to operate independently from women's educational attainment, from their decisions to pursue medical treatments, and from their current status as someone trying or not trying to get pregnant (Ceballo et al. 2015).

The obsession with motherhood - having in mind the high positioning of the social expectation that a woman should be realized in the role of a mother and that infertility deeply affects a woman's experience of herself, it is not surprising that they have a great commitment to the goal of having a child. Many women noted that infertility treatment felt like a second "job" for them - it required changes in their daily routine to accommodate the appointments, it involved physical changes due to medicine, it required planning for treatments, and it caused absences from work (Steuber \& Solomon 2008). Women spend hours searching the Internet, buying books in search of useful tips and alternatives available to them. Making babies - it's the first thing I think of every morning (Parry 2004, 909). In addition to this, the focus on getting pregnant also leads to a kind of control over one's own body. In order to increase the chances of getting pregnant, women look for fertility signs (e.g. the appearance of certain vaginal secretions, body temperature) and thus keep their body under constant surveillance.

\subsection{Stories of infertility}

Knowing that she cannot get pregnant is a kind of loss for every woman. The specificity of this loss is that it is invisible to other people and often the environment is not aware of how many people suffer due to this problem. Women who struggle with infertility feel sad and regret all the things they will not experience: getting pregnant, giving birth, raising children, being a grandmother... (McBain \& Reeves 2019). The theme Stories of infertility includes the most direct stories about women experiencing infertility, their reactions to the knowledge of their infertility, their understanding of the reasons for the infertility.

Reaction to the knowledge of infertility - Confirmed infertility destroys any hope of becoming parents. It is like having a door close on their dream of becoming pregnant or a parent. Along with hopelessness, the question arises - Why me? Women try to understand why this happened to them, what they deserved, what they did wrong, so they are deprived of having children (Ferland \& Caron 2013). They perceive infertility as a punishment, and they do not know how they deserved it.

Constructions of infertility - words, metaphors, stylistic figures that women use to describe infertility say a lot about the very experience of infertility. In the analyzed studies, we found several constructions of infertility that significantly contribute to our understanding of the experience of infertility.

Infertility as an unanticipated disruption in the expected course of their lives. Women who wanted to have children planned to dedicate a part of their lives to children, their upbringing and they were looking forward to the changes that the birth of a child can bring. Infertility prevents this expected sequence of events, forcing them to follow a different path and go in a direction which some women described as 'scary' and 'uncertain' (Ulrich \& Weatherall 2000). 
Infertility as an experience of death. Coping with infertility is described by women as coping with the knowledge of the death of a close person, or even the death of an unborn child (Ferland \& Caron 2013; Ulrich \& Weatherall 2000). Finding out I was infertile was almost as difficult as when my brother got killed in a car accident, For me it was like experiencing the death of a child I never had" (Ferland \& Caron 2013, 186). Comparing infertility with death emphasizes the pain and sorrow that the knowledge of one's infertility brings to a woman.

Infertility as pain that never went away. Women said that being infertile and never having the opportunity to raise their own child was a pain that never went away. This is evidenced by the comment of a woman who is in menopause. She experiences feelings of loss again. I thought I had gotten over it years ago, but when I went through menopause, it was like all those feelings came back - it signaled the end of hope... I did not realize how in the back of my mind I still had hope - after all these years (Ferland \& Caron 2013, 186).

Reasons for infertility - on the way to accepting infertility, women inevitably think about the possible reasons that led to that. As possible reasons, women cite biological problems (e.g.their uterus was small, a low sperm count, the infrequency of menses at a young age), intake of alcohol, negating the drug's possible effectiveness, or uncooperative partners: $M y$ husband was insensitive and didn't take me to the hospital. I didn't go to the hospital myself because I was under his rule (Weinger 2009, 53). Also, there are women who perceive infertility as God's Plan and have no choice but to accept such a fate (Weinger 2009; Ferland \& Caron 2013).

\subsection{All the colors of feelings}

The struggle for offspring is a personal and often traumatic experience for women. It can be colored by different emotions. The term found in the literature to describe the feelings associated with the experience of infertility, and which fully corresponds to the data analyzed in this study, is an emotional roller coaster.

The emotional roller coaster is associated with feelings that change during the menstrual cycle. At the beginning of the cycle, there is hope that conception will occur. It is accompanied by anxiety while waiting for the first signs of conception or menstruation. The onset of menstruation is experienced as a failure followed by pain, sadness, anger. With entry into the new cycle, hope reappears (Bell 2013; Mete, Fata \& AluşTokat 2020; Parry 2004). I felt like I was on an emotional roller coaster. I started out each month full of hope, then I would crash down and then start all over again (Parry 2004, 913). In the analyzed studies, women spoke separately about certain emotions.

Anger can be directed towards oneself, close relatives, friends who are pregnant, partners who are fertile, the world, and even God (Fernandes, Papaikonomou \& Nieuwoudt 2006; Mete et al. 2020). Many described feeling angry and upset if they witnessed negative behavior toward children, such as verbal abuse, physical punishment, or perceived neglect, and at women who chose abortion (Bell 2013; Fernandes et al. 2006).

Hypersensitivity. Because of this negative experience women can become hypersensitive and tend to cry more often. Crying can be triggered by countless situations, starting with a movie, a sad story they heard until they found out that a woman they know has become pregnant. If I hear about someone conceiving, it upsets me for days - even if I'm at work, if I hear about someone who is pregnant, I have to try really hard not to cry (Parry 2004, 918).

Jealousy. Women who struggle with infertility talk about jealousy towards women who are pregnant or have children. Jealousy is accompanied by a feeling of injustice 
because some women have more children, and they have none. I found out today my friend Heidi is pregnant. I wanted to be happy for her, and normally I would be, but today I felt a little uncomfortable. Actually, I think I was secretly a little jealous because David and I have been trying with no luck (Parry 2004, 916).

Blame. Because pregnancy is visibly located in women's bodies, women may be more likely than men to feel ashamed and to blame themselves for infertility (Ceballo, Graham \& Hart 2015; Ferland \& Caron 2013). Also, blame was more likely to be experienced by people who had been coping with infertility for a long time. Some individuals cast blame on their partner, especially if it was perceived that the reason for the infertility was something within their control (e.g., a previous vasectomy, poor health habits), whereas others who were medically responsible for the infertility felt guilt or self-blame when they witnessed their partners suffering due to their inability to reproduction (Steuber \& Solomon 2008).

The grief that women feel is specific because of its cyclical nature. It follows every failed attempt to conceive, of which the symbolic expression is the onset of menstruation. The ongoing grief and ambiguity that the women experienced made it difficult for them to find a sense of peace and heal while they were actively trying to conceive. Another specificity of grief is reflected in the fact that it is related outwardly to the invisible loss for which there are no social rituals or customs that will help in the grieving process. The grief of an infertile woman does not fit within the traditional societal norms of grieving, thus inhibiting their ability to publicly mourn their loss (McBain \& Reeves 2019).

\subsection{Identity changes}

The experience of infertility deeply affects and changes every woman. Her world, thoughts, beliefs, desires change in such a way that the individual is unable to remain the same. Under the influence of intense and negative emotions that occur in the process of grief, a woman may see herself as worthless, 'defective', and unable to control her life in terms of her physical and emotional capabilities (Fernandes et al. 2006). Also, she may feel worthless and perceive others as pitying or even mocking her (Mete et al. 2020). Belief that infertility is a woman's problem can often be heard in women's narratives. No matter what the cause of infertility, a woman may feel that it is her fault and that it was not "natural" for a woman not to be able to become pregnant naturally (Bell 2013; Mete et al. 2020). Both partners may have difficulty accepting the identity of the biological non-parent and acceptance of infertility marks an important point in this couple's relationship. On the infertility forums, a collectivist orientation is a frequent occurrence and some people use it when discussing their infertility journey. Many bloggers adopted a "we" approach to narrating their stories. The We approach or Our history emphasizes the connection of partners and their closeness in the fight against infertility (Steuber \& Solomon 2008). In addition to the negative experience of themselves, there are women who point out that they do not want to be identified with an infertile woman, whose meaning often implies a negative connotation (e.g. a 'poor woman' who can't have children, somehow faulty, deviant, or pitiable). They show agency and resistance to the notion that womanhood - or femininity - hinges on motherhood (Bell 2013).

\subsection{The complexity of the partnership}

No matter what leads to problems in conception, it becomes a problem for both partners. The changes that occur in the partnership are complex and in the analysis of selected articles 
they are grouped into three subtopics: Emotional relationship and partner support, Relational uncertainty, and The change in the partners' sex lives.

Emotional relationship and partner support. The experience of infertility affects the partnership and can contribute to both distance and grater connection of the partner. Some women imposed hiding feelings and distance in their relationships with their spouses and partners, because they feel that the experience of infertility is not equally painful for them (Ceballo et al. 2015; Mete et al. 2020). Also, some woman describe that the experience of infertility only strengthened their partnership. My husband and I are closer now and actually closer than most couples we know - we only have each other (Ferland \& Caron 2013, 186). Women emphasize the importance of spousal support (McBain \& Reeves 2019) but often do not receive it. Instrumental support issues were often coupled with emotional support deficiencies, such that partners felt that compassion, empathy, or companionship were lacking (Steuber \& Solomon 2008). It was a cycle of peaks and valleys, and I felt like I was going through it alone (Parry 2004, 913).

Relational uncertainty. The dynamics and stability of a partnership can often be disrupted when partners struggle with infertility. The reasons for partner instability can be numerous. Doubts about the relationship emerge when partners are differently invested in infertility treatments. Some women can feel the frustration when their partners did too little of the work involved in the fertility treatment. Also, relational uncertainty was especially prevalent among those partners who were the source of infertility and blaming themselves for the infertility they brought into the partnership. When partners reach the decision to stop trying to conceive independently or at different times, those differences might seriously undermine the relationship (Steuber \& Solomon 2008)

The change in the partners' sex lives - because there is high focus on achieving conception, sex between partners becomes more of an obligation and a means to an end, rather than an expression of love and intimacy. Many women found that sex became "routine", "mechanical" or "almost like a scheduled event" (Steuber \& Solomon 2008, 844). Because sexual intercourse is often task-oriented and under pressure, their desire and ability to enjoy sex also decreases (Ferland \& Caron 2013).

\subsection{Social environment (social support)}

Social support that comes from family members, closest relatives, and friends can significantly help women cope with the feelings that accompany the experience of infertility. However, the experiences of women with social support are different. There are women who talk about positive reactions from friends and family members (Bell 2013), but also those who have distanced themselves from close friends due to a lack of adequate support. They felt like no one really understood what they were going through (Fernandes et al. 2006; McBain \& Reeves 2019). Many women state that they find the most support and understanding in people who are struggling with the same problem, whether it is other couples who are struggling with infertility or support groups for infertile women. We met another couple (Lola and Brian) struggling with the exact same problems. It was just so wonderful to be able to talk for hours about the problems without people getting tired of hearing about it (Parry 2004, 918). This core themes include two subthemes - Negative reactions of the environment and Reaction to the environment.

Negative reactions of the environment include those behaviors that come from family members and friends, and that were in some way hurtful to women. 
Hurtful comments or solutions refer to inappropriate and insensitive comments and suggestions that made women feel bad (Bell 2013; Ferland \& Caron 2013; McBain, Reeves 2019; Parry 2004). My family hasn't been so great - some of their comments (just relax and have fun trying or it takes everyone a little while, don't worry, you'll conceive) have really hurt my feelings (Parry 2004, 916).

Being excluded or ignored. Many women felt isolated and separated from the world, their community, family, and friends at a time when they most needed to be supported (Ferland \& Caron 2013; McBain \& Reeves 2019; Weinger 2009; Fernandes et al. 2006). No one ever included me in things because I didn't have kids (Ferland \& Caron 2013, 185). Some of them talk about friends who invited only those with biological children to their child's birthday party (Weinger 2009).

Different status at work. The experience of some women was that they were treated differently at work because they did not have children. They did not have the same privileges as women with children or stayed at work longer than them. It is as if they can use me at any time of day (Weinger 2009, 56).

Reaction to the environment refers to the ways in which women have reacted to inappropriate comments or behavior from people in their environment.

Silence and isolation. The majority of women described silence and isolation as the defining features of their relationships with other people (Ceballo et al. 2015; Mete et al. 2020; Parry 2004; Weinger 2009). They described experiencing extreme loneliness and identified few, if any, people with whom they felt comfortable talking about their experiences with infertility (Mete et al. 2020). The pain is severe; you are kept at a distance by some friends and husband's relations. (Weinger 2009, 55).

Denial. The analysis shows that some women were contradictory in their responses about environmental reactions. They would first say that they did not experience any discomfort or inappropriate comments and would only later describe a situation in which other women moved away from them and did not want to befriend them. Perhaps some women moved between reality and denial as a method of coping with a condition of great loss that is severely stigmatizing (Weinger 2009).

Conformity. Some childless women are careful to conform to societal norms in order not to incur societal disapproval, blame, wrath, and exclusion. Being childless almost necessitates exuding a good mood, being pleasant to everyone, and taking care not to ruffle anybody's feathers (Weinger 2009).

A direct approach involves direct answers to inappropriate questions or comments. After such answers inappropriate questions are not repeated. My husband starting saying we are actually having trouble falling pregnant, and it would really shut people up (Bell 2013 , 290). Related to this is a strategy of having a reserve of responses to pull out when struck by potentially wounding comments (Weinger 2009).

Humor. Some women had tried to dismiss these types of questions using humor to defuse the lines of inquiry about childlessness. They'd ask, 'When are you going to have a baby?' And I'd just say practice makes perfect. (Bell 2013, 290).

\subsection{Coping strategies}

Ways of dealing with the problem of infertility can be different. Women can use different strategies depending on their emotional and cognitive state, life philosophy, current life circumstances, and number of years spent trying to conceive. 
Insufficient coping most often occurs as a reaction to becoming aware of one's infertility. It includes crying, indecisiveness, crying out, rebelling, the inability to concentrate, intolerance (Bell 2013; Mete et al. 2020)

Rationalization includes the life philosophy that although a woman does not have a child, she has things that others do not have, such as a college degree, a job, and a committed companion (Weinger 2009).

Hope that they will still have a child helped women. If there is no man - fine; if no children - OK. I try and make myself happy (Weinger 2009, 59).

Religion. Some women turn to God and praying to accept loss (Mete et al. 2020; Parry 2004). It's God's plan' so she just has to accept it. (Weinger 2009, 58).

I have had enough! After numerous failed attempts, medical interventions, medications, some women reached a point where they knew they had to stop trying to get pregnant (Ferland \& Caron 2013). It is a kind of coping that requires a lot of strength - to stop fighting for offspring.

A mother in the other ways. Some women who could not have their biological children found different ways to experience motherhood. Some raised non-biological children (Weinger 2009), some were dedicated to the children of their relatives. I am the special aunt to my brother's daughters. They know they can talk to me like a mother if they can't talk to their parents. We are very, very close. (Ferland \& Caron 2013, 186).

\section{CONCLUSION}

In this article, we dealt with the subjective experience of infertility, the feelings, thoughts and problems faced by infertile women. Thus, the analysis of selected qualitative studies aimed to understand the lived experience of infertile women. The results of the applied thematic analysis show that the experience of infertility is traumatic and painful for women in many ways. Because of the social expectation that a woman should fulfill the role of mother, women may feel incomplete or experience their body as damaged and dysfunctional (Caballo et al. 2015; Ferland \& Caron 2013; Urlih \& Weatherall 2000). They are highly focused on getting pregnant and committed to achieving that goal so much so that they perceive it as their second job (Parry 2004; Steuber \& Solomon 2008). During the struggle for offspring, they think about why this is happening to them, what the reasons for their infertility are (Ferland \& Caron 2013; Weinger 2009). The struggle for offspring is often long and exhausting and changes women in many ways. They may feel worthless, defective, they may notice that others are mocking or pitying them (Fernandes et al. 2006; Mete et al. 2020), they may blame themselves for the infertility even when they are not the cause of the problem (Bell 2013; Mete et al. 2020). They can also show agency and resist identification with an infertile woman, as the meaning often implies a negative connotation (Bell 2013). Their feelings are varied and aligned with the phases of the menstrual cycle. Hope appears first, then anxiety, patience, disappointment, anger, rage. With a new cycle, hope awakens again (Bell 2013; Mete et al. 2020; Parry 2004). Every unsuccessful attempt to conceive represents a specific form of loss that is not outwardly visible, and which is extremely painful (McBain \& Reeves 2019). Proof of this is the comparison of infertility with the death of a close person or with the death of an unborn child (Ferland \& Caron 2013; Ulrich \& Weatherall 2000). Infertility affects and changes the partnership in several ways. It can lead to the alienation of partners (Ceballo et al. 2015; Mete et al. 2020) or to their greater intimacy (Ferland \& Caron 2013). Partner support is very important to women 
(McBain \& Reeves 2019) but they often do not have it (Parry 2004; Steuber \& Solomon 2008). Partnership problems can arise because of a difference in commitment to problem solving, different expectations, disagreements about treatment choices, or decisions about when to stop trying and accept infertility (Steuber \& Solomon 2008). Infertility significantly affects the partners'sex life and makes it "routine", "mechanical" or "almost like a scheduled event" (Ferland \& Caron 2013; Steuber \& Solomon 2008). Relationships with family members and friends can be significantly changed. The reactions of close people can be unsupportive and insensitive, most often due to inappropriate comments or advice (Bell 2013; Ferland \& Caron 2013; McBain \& Reeves 2019; Parry 2004). Also, many women say they have felt excluded and rejected by their friends or relatives (Ferland \& Caron 2013; Fernandes et al. 2006; McBain \& Reeves 2019; Weinger 2009). Their reactions to inappropriate advice and behavior may be different. They can respond with silence and isolation (Ceballo et al. 2015; Mete et al. 2020; Parry 2004; Weinger 2009), but also with direct response and humor (Bell 2013; Weinger 2009).In the fight against infertility, they rely on different coping strategies. Insufficient coping refers to crying, and non-acceptance, and is associated with the knowledge of one's infertility (Bell 2013; Mete et al. 2020). Some women try to deal with the problem by rationalizing it (Weinger 2009), while others find relief in religion and understanding that infertility is God's plan (Mete et al. 2020; Parry 2004; Weinger 2009). Hope helps them persevere in their struggle for offspring (Weinger 2009). After numerous failed attempts, they come to the point where they realize and accept that further efforts and attempts are in vain and that they must accept their infertility (Ferland \& Caron 2013). They can then expand their understanding of motherhood and focus on caring for the children of their relatives or friends (Ferland \& Caron 2013; Weinger 2009).

Dominant discursive constructions of infertility have a negative connotation. Examples of this are everyday terms such as "barren" and "sterile", "unfruitful", which convey a sense of emptiness and inadequacy. For this reason, some authors point out that it is necessary to adopt new constructions that do not have a negative connotation and that are more supportive for women. One such construction is "women who want but who are unable to have children". Finally, far from being mad, bad and desperate, involuntarily infertile women can be construed as survivors. They are people who have had to confront loss, grief and feelings of failure (Ulrich \& Weatherall 2000).

The results of this review of qualitative research reveal different aspects of the lived experiences of an infertile woman. This review provides an insight into the diversity of thoughts, feelings, ideas, behaviors and problems that can be found in women's narratives about experiences with infertility. As such, we believe that the insights gained in this study could have practical implications for support and provision of services to women with infertility.

\section{REFERENCES}

Abbey, A., F. M. Andrews, \& L. J. Halman. “Gender's role in responses to infertility”. Psychology of Women Quarterly 15 (1991): 295-316. doi: 10.1111/j.1471-6402.1991.tb00798.x

Bell, K. "Constructions of 'Infertility' and Some Lived Experiences of Involuntary Childlessness". Affilia: Journal of Women and Social Work 28, 3 (2013): 284-295. doi: 10.1177/0886109913495726

Blyth, E., \& R. Moore. "Involuntary childlessness and stigma". In Stigma and social exclusion in healthcare, edited by T. Mason, C. Carliste, \& E. Whitehead, 217-245. London and England: Routledge, 2001.

Braun, V. \& V. Clarke. "Using thematic analysis in psychology". Qualitative Research in Psychology 3 (2006): 77-101. doi: 10.1191/1478088706qp063oa 
Ceballo, R., T. E. Graham, \& J. Hart. "Silent and Infertile: An Intersectional Analysis of the Experiences of Socioeconomically Diverse African American Women with Infertility". Psychology of Women Quarterly 39, 4 (2015): 497-511. doi: 10.1177/0361684315581169

Centers for Disease Control and Prevention. Infertility FAQs (Reproductive Health). Accessed July 6, 2020. https://www.cdc.gov/reproductivehealth/Infertility/index.htm

Culley, L., N. Hudson, \& M. Hohan. "Where are all the men? The marginalization of men in social scientific research on infertility". Reproductive BioMedicine Online 27 (2013): 225-235. doi: 10.1016/j.rbmo.2013.06.009

Fekkes, M., S. Buitenijk, G. Verrips, D. Braat, A. Braeways, J. Dolfing... N. Macklon. "Health related quality of life in relation to gender and age in couples planning IVF treatment". Human Reproduction 18 (2003): 1536-1543. doi.org/10.1093/humrep/deg276

Ferland, P., \& L. S. Caron. "Exploring the Long-term Impact of Female Infertility: A Qualitative Analysis of Interviews with Postmenopausal Women who Remained Childless". The Family Journal: Counseling and Therapy for Couples and Families 21, 2 (2013): 180-188. doi: 10.1177/1066480712466813

Fernandes, P., M. Papaikonomou, \& J. M. Nieuwoudt. "Women suffering through their Bodies". South African Journal of Psychology 36, 4 (2006): 851-879. doi: 10.1177/008124630603600412

Gerrity, A. D. "Biopsychosocial Theory of Infertility". The Family Journal: Counseling and Therapy for Couples and Families 9, 2 (2001): 151-158. doi: 10.1177/1066480701092009

Hammerberg, K., J. Astbury, \& H. W. B. Baker. "Women's experience of IVF: A follow-up study". Human Reproduction 16 (2001): 374-383. doi: 10.1093/humrep/16.2.374

McBain, D. T \& P. Reeves. "Women's Experience of Infertility and Disenfranchised Grief". The Family Journal: Counseling and Therapy for Couples and Families 27, 2 (2019): 156-166. doi: 10.1177/1066480719833418

Mete, S., S. Fata, \& M. Aluş Tokat. "Feelings, opinions and experiences of Turkish women with infertility: A qualitative study". Health Informatics Journal 26, 1 (2020): 528-538. doi: 10.1177/1460458219839628

Mindes, E. J., K. M. Ingram, W. Kliewer, \& C. A. James. "Longitudinal analyses of the relationship between unsupportive social interactions and psychological adjustment among women with fertility problems". Social Science \& Medicine 56 (2003): 2165-2180. doi: 10.1016/s0277-9536(02)00221-6.

Parry, C. D. "Understanding Women's Lived Experiences with Infertility: Five Short Stories". Qualitative Inquiry 10, 6 (2004): 909-922. doi: 10.1177/1077800403261852

Slade, P., J. Emery, \& B. A. Lieberman. "A prospective, longitudinal study of emotions and relationships in invitro fertilization treatment". Human Reproduction 12 (1997): 183-190. doi: 10.1093/humrep/12.1.183

Steuber, R. K. \& H. D. Solomon. "Relational uncertainty, partner interference, and infertility: A qualitative study of discourse within online forums". Journal of Social and Personal Relationships 25, 5(2008): 831855. doi: 10.1177/0265407508096698

Ulrich, M., \& A. Weatherall. "Motherhood and Infertility: Viewing Motherhood through the Lens of Infertility". Feminism \& Psychology 10, 3(2000): 323-336. doi: 0959-3535(200008)10:3;323-336;013561

Vilig, K. Kvalitativna istraživanja u psihologiji. Beograd: Clio, 2013.

Weinger, S. "Infertile' Cameroonian Women Social Marginalization and Coping Strategies". Qualitative Social Work 8, 1(2009): 45-64. doi: 10.1177/1473325008100425

World Health Organization. Infertility Definitions and Terminology (Sexual and Reproductive Health). Accessed July 7, 2020. http://www.who.int/reproductive health/topics/infertility/definitions/en/.

\section{ŽIVOTNA ISKUSTVA ŽENA SA NEPLODNOŠĆU - PREGLED KVALITATIVNIH ISTRAŽIVANJA}

U ovom radu bavili smo se analizom iskustva i doživljajem žena koje se suočavaju sa neplodnošću. Interesovalo nas je šta se o njihovim osećanjima, razmišljanjima, problemima može saznati analizom rezultata dobijenih u kvalitativnim istraživanjima. Analizirali smo 10 kvalitatvnih studija koje se bave iskustvom žena sa neplodnošću. Tematskom analizom izabrnih studija izdvojili smo sedam glavnih tema: Materinsvo, Priče o neplodnosti, Sve boje osećanja, Promene identiteta, Kompleksnost partnerskog odnosa, Socijalno okruženje (socijalna podrška), Strategije suočavanja. Svaka izdvojen aglavna tema obuhvata I određenji broj podtema. U radu se detaljno obrazlaže svaka izdvojena tema, a njihovo utemeljenje se potkrepljuje odgovarajućim citatima.

Ključne reči: neplodnost, žene, iskustvo, kvalitativna istraživanja. 